\title{
PENGARUH STORE ATMOSPHERE TERHADAP KEPUTUSAN PEMBELIAN KONSUMEN (Studi pada konsumen Rumah Makan Inggil di Kota Malang)
}

\author{
Cundhamani Caraka Gana \\ Department of Management FEB UMM \\ E-mail: carakagana@gmail.com
}

\begin{abstract}
The purpose of this study was to determine the effect of store atmosphere consisting of instore atmosphere and outstore atmosphere on purchasing decisions and to find out the store atmosphere that consists of instore atmosphere and atmosphere outstore the dominant influence on the purchase decision. This type of research is (descriptive reasearch) with a quantitative approach, using primary data taken from questionnaire respondents, namely consumer Inggil Restaurant in Malang. The sampling technique using a non-probability sampling with a sample size of 100 respondents. Data were analyzed using multiple linear regression analysis.Based on the results of research and discussion that has been done it can be concluded that 1) there are significant atmosphere and outstore atmosphere instore partially and simultaneously on purchasing decisions and 2) instore atmosphere as dominant influence on purchase decisions Inggil Restaurant in Malang.
\end{abstract}

Keywords: store atmosphere, instore atmosphere, outstoreatmosphere, purchasing decisions.

\section{PENDAHULUAN}

Bisnis merupakan suatu kegiatan atau aktivitas yang dikerjakan oleh perusahaan untuk mencari keuntungan atau nilai tambah. Saat ini perkembangan bisnis di Indonesia sudah semakin berkembang. Perkembangan bisnis tersebut juga dialami di kota Malang. Bisnis kuliner merupakan bisnis yang menjadi salah satu pilihan para pebisnis untuk dijalankan karena memiliki prospek yang baik.

Perilaku konsumen melibatkan interkasi antara pengaruh afeksi dan kognisi, perilaku dan kejadian di sekitar. Untuk memahami konsumen dan mengembangkan strategi pemasaran perusahaan harus memahami apa yang dipikirkan (kognisi), apa yang dirasakan (afeksi), dan apa yang konsumen lakukan, serta kejadian sekitar yang mempengaruhi dan dipengaruhi oleh apa yang dipikirkan, dirasa, dan dilakukan konsumen. Berbagai macam bisnis di bidang kuliner mulai dari warung makanan di pinggir jalan, kafe-kafe, hingga resto-resto besar, yang tetap ramai dikunjungi pengunjung, artinya adalah persaingan yang terjadi di antara pebisnis kuliner itu sendiri akan semakin ketat pula, sehingga memaksa para pemilik bisnis kuliner memutar otak lebih keras lagi menyiapkan strategi yang tepat demi memenangkan persaingan di pasar. 
Perusahaan harus berfokus pada konsumen, konsumen adalah bagian terpenting dalam perusahaan. Oleh karena itu perusahaan harus mengerti bagaimana konsumennya

berperilaku. Dalam menarik konsumen untuk melakukan pembelian, bisnis harus mampu menerapkan konsep pemasaran yang tepat sesuai dengan kondisi pasar yang ada. Konsep pemasaran bertujuan memberikan kepuasan terhadap keinginan dan kebutuhan konsumen.

Harga dan kualitas pelayanan tidak lagi menjadi bahan pertimbangan utama bagi para penikmat kuliner, saat ini atmosphere menjadi faktor penting bagi seorang konsumen dalam memilih tempat untuk bersantap. Atmosphere rumah makan yang nyaman dengan dekorasi yang unik menjadi daya tarik tersendiri bagi sebuah rumah makan yang membuat konsumen memutuskan untuk mengunjungi rumah makan tersebut. Bahkan tidak jarang konsumen memutuskan untuk mengunjungi suatu rumah makan karena menyukai atmosphere yang ditawarkan rumah makan tersebut. Store atmosphere dapat dikatakan sebagai komponen penting dari sebuah toko atau rumah makan dan bisa memberikan efek sensorik dominan yang diciptakan dari sebuah desain toko atau rumah makan, maka suatu rumah makan harus membentuk suasana yang sesuai dengan pasar sasarannya.

Ada berbagai macam rumah makan yang ada di kota Malang, oleh karena itu persaingan dibidang usaha rumah makan tidak dapat dihindarkan. Berbagai upaya pemilik berlomba-lomba menawarkan konsep rumah makan yang beragam untuk menarik konsumen agar mengunjungi rumah makan.

Rumah Makan Inggil merupakan salah satu rumah makan terkenal di Kota Malang terletak di jalan Gajahmada No 4 Klojen yang hadir dengan menggabungkan konsep resto, museum, pertunjukan seni sekaligus menikmati kuliner khas masakan Jawa. Bangunan restoran ditata seperti galeri pameran maupun museum dan nuansa khas tempo dulu langsung terasa ketika memasuki bangunan resto sekaligus museum Inggil ini, berbagai benda-benda kuno seperti sepeda kuno, alat pemutar piringan hitam, telepon jadul, mesin ketik, mesin jahit dan radio tertata rapi dan terawat di berbagai sudut rumah makan Inggil. Sensasi tempo dulu di rumah makan Inggil ini memiliki banyak ciri khas etnik dari Jawa Timur. Yang didekor mirip seperti galeri di zaman kolonial Belanda.Sambil menikmati menu hidangan, lagu-lagu lama dan tembang-tembang jawa juga akan senantiasa menemani waktu bersantap selama berada disana. Pramusaji mengenakan pakaian khas Jawa, sehingga tak salah jika banyak wisatawan asing juga betah duduk lama sambil berkeliling restoran melihat aneka benda antik koleksi. Suasana Rumah Makan Inggil yang nyaman, asri dengan panorama tempo dulu semakin menambah selera makan pengunjung. Rumah Makan Inggil menjadi salah satu destinasi para turis, baik asing maupun domestik jika berwisata kuliner di Malang. Hal ini dapat dilihat pada Tabel 1. Tingkat kunjungan di inggil dari tahun 20132015 mengalami peningkatan yang 
sangat signifikan. Peningkatan tersebut dikarena pelaku usaha selalu menjaga store atmosphere yang membuat pengunjung betah berlamalama dan berdampak pada peningkatan pengunjung.

Tabel 1. Jumlah Kunjungan di Rumah Makan Inggil

\begin{tabular}{ccc}
\hline No & Tahun & Jumlah Kunjungan \\
\hline 1 & 2013 & 18.720 \\
2 & 2014 & 24.120 \\
3 & 2015 & 26.640 \\
\hline
\end{tabular}

\section{TINJAUAN PUSTAKA}

Perilaku konsumen pada hakikatnya untuk memahami Mengapa konsumen melakukan dan apa yang mereka lakukan. Schiffman dan Kanuk (2008:6) mengemukakan bahwa studi perilaku konsumen $\begin{array}{lcr}\text { adalah suatu } & \text { studi } & \text { mengenai } \\ \text { bagaimana } & \text { seorang } & \text { individu } \\ \text { membuat } & \text { keputusan } & \text { untuk }\end{array}$ mengalokasikan sumber daya yang tersedia (waktu, uang, usaha, dan energi).

Definisikan perilaku konsumen menurut Kotler dan Keller (2008:214) Perilaku konsumen adalah studi bagaimana individu, kelompok dan organisasi memilih, membeli, menggunakan dan menempatkan barang, jasa, ide atau pengalaman untuk memuaskan keinginan dan kebutuhan mereka. Dalam sub bab berikut akan dijelaskan mengenai perilaku pembelian konsumen. Kotler (2008:226) menggambarkan model perilaku konsumen sebagai berikut:

\begin{tabular}{|c|c|c|c|c|}
\hline $\begin{array}{l}\text { Rangsangan } \\
\text { Pemasaran }\end{array}$ & $\begin{array}{l}\text { Rangsangan } \\
\text { Lain }\end{array}$ & $\begin{array}{l}\text { Ciri-ciri } \\
\text { Pembeli }\end{array}$ & $\begin{array}{l}\text { Proses Keputusan } \\
\text { Pembelian }\end{array}$ & $\begin{array}{c}\text { Keputusan } \\
\text { Pembeli }\end{array}$ \\
\hline Produk & Ekonomi & Budaya & Pemahaman masalah & Pemilihan produk \\
\hline Harga & Teknologi & Sosial & Pencarian Informasi & Pemilihan merek \\
\hline $\begin{array}{l}\text { Saluran } \\
\text { Pemasaran }\end{array}$ & & Pribadi & & $\begin{array}{l}\text { Pemilihan saluran } \\
\text { pembelian }\end{array}$ \\
\hline Promosi & Budaya & Psikologi & Keputusan Pembelian & $\begin{array}{l}\text { Penentuan waktu } \\
\text { pembelian }\end{array}$ \\
\hline & & & & Jumlah Pembelian \\
\hline
\end{tabular}

Gambar 1. Model Perilaku Konsumen

Store Atmosphere adalah suasana terencana yang sesuai dengan pasar sasarannya dan yang dapat menarik konsumen untuk membeli (Kotler 2005). Store atmosphere menyebabkan atau mempengaruhi pembelian. Keadaan emosional akan membuat dua perasaan yang dominan yaitu perasaan senang dan membangkitkan keinginan. Cakupan strategi Store atmosphere bisa dikelompokan menjadi Instore dan Outstore."Store atmosphere bisa dipahami sebagai penataan ruang dalam (instore) dan ruang luar (outstore) yang dapat menciptakan kenyamanan bagi pelanggan",(Sutisna dan Pawitra 2001). Menurut Levi dan Weitz (2001: 118), Store atmosphere terdiri dari dua hal, yaitu instore atmosphere dan out store atmosphere. Instore Atmosphere adalah pengaturan-pengaturan di dalam ruangan yang menyangkut, (1) internal layout yaitu pengaturan dari berbagai fasilitas dalam ruangan yang terdiri dari tata letak meja kursi pengunjung, tata letak meja kasir, dan tata letak lampu, pendingin 
ruangan, sound, (2) Suara merupakan keseluruhan alunan suara yang dihadirkan dalam ruangan untuk menciptakan kesan rileks yang terdiri dari live music yang disajikan restoran dan alunan suara musik dari sound system, (3) bau merupakan aroma-aroma yang dihadirkan dalam ruangan untuk menciptakan selera makan yang timbul dari aroma makanan dan minuman dan aroma yang ditimbulkan oleh pewangi ruangan, (4) tekstur merupakan tampilan fisik dari bahan-bahan yang digunakan untuk meja kursi dalam ruangan dan dinding ruangan, (5) desain interior bangunan adalah penataan ruang-ruang dalam restoran kesesuaian meliputi kesesuaian luas ruang pengunjung dengan ruas jalan yang memberikan kenyamanan, desain bar counter, penataan meja, penataan lukisan-lukisan, dan sistem pencahayaan dalam ruangan.

Outstore atmosphere adalah pengaturan-pengaturan di luar ruangan yangmenyangkut, (1) external layout yaitu pengaturan tata letak berbagai fasilitas restoran diluar ruangan yang meliputi tata letak parkir pengunjung, tata letak papan nama, dan lokasi yang strategis, (2) tekstur yaitu tampilan fisik dari bahan-bahan yang digunakan bangunan maupun fasilitas diluar ruangan yang meliputi tekstur dinding bangunan luar ruangan dan tekstur papan nama luar ruangan, (3) desain eksterior bangunan merupakan penataan ruanganruangan luar restoran meliputi desain papan nama luar ruangan, penempatan pintu masuk, bentuk bangunan dilihat dari luar, dan sistem pencahayaan luar ruangan. Keputusan pembelian, pemahaman kebutuhan dan proses pembelian konsumen adalah sangat penting dalam membangun strategi pemasaran yang efektif. Dengan mengerti bagaimana pembeli melalui proses pengenalan masalah, pencarian informasi, mengevaluasi alternatif, memutuskan membeli, dan perilaku setelah membeli para pemasar dapat mengambil isyaratisyarat penting bagaimana memenuhi kebutuhan pembeli. Perilaku konsumen akan menentukan proses pengambilan keputusan dalam pembelian mereka. Proses pengambilan keputusan tersebut merupakan sebuah pendekatan penyelesaian masalah yang terdiri atas lima tahap (Kotler, 2008:234) yaitu:

Pengenalan masalah, penganalisaan keinginan dan kebutuhan ini ditujukan terutama untuk mengetahui adanya keinginan dan kebutuhan yang belum terpenuhi dan belum terpuaskan. Pencarian informasi, konsumen yang tergugah kebutuhannya akan terdorong untuk mencari informasi yang lebih banyak mengenai produk atau jasa yang ia butuhkan. Evaluasi alternatif, tahap ini meliputi dua tahap, yaitu menetapkan tujuan pembelian dan menilai serta mengadakan seleksi terhadap alternatif pembelian berdasarkan tujuan pembeliannya. Keputusan pembelian, keputusan untuk membeli disini merupakan proses pembelian yang nyata. Jadi, setelah tahap-tahap dimuka dilakukan maka konsumen harus mengambil keputusan apakah membeli atau tidak. Perilaku pascapembelian, setelah membeli produk, konsumen akan mengalami level kepuasan atau ketidakpuasan. 
Tugas pemasar tidak berakhir saat produk dibeli, melainkan berlanjut hingga periode pascapembelian. Berdasarkan tinjauan pustaka yang telah dikemukakan, maka model konseptual dalam penelitian ini dapat dilihat pada Gambar 2. sebagai berikut:

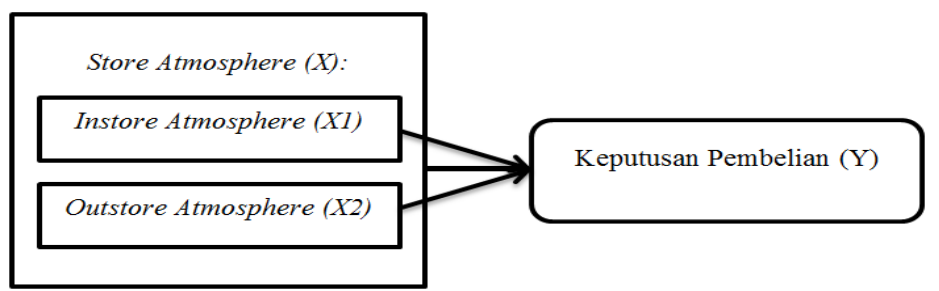

Gambar 2. Model Konseptual Penelitian

H1: Store atmosphere yang terdiri dari instore atmosphere dan outstore atmosphere berngaruh terhadap keputusan pembelian konsumen.

$H 2$ : Instore atmosphere berngaruh dominan terhadap keputusan pembelian konsumen.

\section{METODE PENELITIAN}

Penelitian ini dilakukan di Rumah Makan Inggil Kota Malang. Jenis penelitian yang digunakan dalam penelitian ini adalah penelitian deskriptif dengan pendekatan kuantitatif. Pada penelitian ini, populasi yang diambil adalah konsumen yang telah membeli pada Rumah Makan Inggilyang terletak di Jl. Gajah Mada No. 4, Kota Malang. Metode yang digunakan adalah teknik Accidental Sampling, yaitu siapa saja yang secara kebetulan bertemu dengan peneliti dapat digunakan sebagai sampel, bila dipandang orang yang kebetulan ditemui itu cocok sebagai sumber (Sujarweni, 2015). Pengumpulan data dalam penelitian ini menggunakan metode kuesioner. Bentuk kuesioner yang akan dibuat adalah kuesioner yang disusun berdasarkan item-item dengan menggunakan metode skala likert. Teknik pengukuran variabel dalam penelitian ini menggunakan skala Likert lima tingkat.

Definisi operasional variabel yang digunakan dalam penelitian ini adalah sebagai berikut: Store Atmosphere (X) suasana yang di tawarkan Rumah Makan Inggil kepada konsumen atau calon konsumen berupa ruang dalam dan ruang luar agar dapat menarik konsumen untuk melakukan pembelian. Instore Atmosphere (X1): Pengaturan di dalam ruangan Rumah Makan Inggil yang membuat konsumen merasa nyaman, dengan indikator: Tata letak meja kursi pengunjung yang tertata rapi, Tata letak lukisan atau pajangan yang indah, Tata letak lampu yang menarik, Tata letak panggung musik yang tepat atau nyaman, Alunan musik sesuai konsep khas Jawa Timur tempo dulu, Bau pewangi di dalam ruangan yang segar, Meja kursi sesuai dengan konsep khas Jawa Timur tempo dulu, Warna dinding serasi dengan konsep di dalam ruangan, Desain pajangan di dinding bagus atau artistik.

Outstore Atmosphere (X2) pengaturan di luar ruangan Rumah Makan Inggil yang membuat konsumen tertarik, dengan indikator: Letak papan nama terlihat jelas, 
Letak parkir yang nyaman, Pepohonan rindang di depan bangunan yang menyejukkan, Tekstur dinding luar ruangan yang bagus, Tekstur papan nama klasik yang menarik, Bentuk bangunan menawan yang elegan, Model dasain papan nama yang klasik. Keputusan Pembelian (Y) merupakan keputusan konsumen dalam menetapkan pembelian makanan dan minuman di Rumah Makan Inggil, dengan indikator: Konsumen mantap membeli pada Rumah Makan Inggil dan konsumen berkeyakinan untuk memutuskan membeli makanan pada Rumah Makan Inggil.

\section{HASIL PENELITIAN DAN PEMBAHASAN}

Tabel 2. meunjukkan hasi uji validitas yang menggambarkan bahwa indikator variabel instore atmosphere yang berjumlah 9 item dapat mengukur tentang variabel instore atmosphere. Variabel outstore atmosphere yang berjumlah 7 item indikator yang semua indikator valid, jadi semua indikator outstore atmosphere dapat mengukur variabel outstore atmosphere dan semua indikator tersebut valid, atau layak untuk mengukur variabel dalam penelitian ini.

Tabel 2. Hasil Uji Validitas

\begin{tabular}{cccc}
\hline Variabel & Koefisien Korelasi & R Tabel & Keterangan \\
\hline & 0,716 & 0,195 & Valid \\
& 0,642 & 0,195 & Valid \\
& 0,741 & 0,195 & Valid \\
Instore Atmosphere & 0,728 & 0,195 & Valid \\
X1 & 0,710 & 0,195 & Valid \\
& 0,600 & 0,195 & Valid \\
& 0,677 & 0,195 & Valid \\
& 0,704 & 0,195 & Valid \\
& 0,747 & 0,195 & Valid \\
Outstore & 0,705 & 0,195 & Valid \\
Atmosphere & 0,823 & 0,195 & Valid \\
X1 & 0,569 & 0,195 & Valid \\
& 0,759 & 0,195 & Valid \\
& 0,547 & 0,195 & Valid \\
Kebutuhan Pembelian & 0,665 & 0,195 & Valid \\
Y & 0,804 & 0,195 & Valid \\
& 0,781 & 0,195 & Valid \\
\hline
\end{tabular}

Tabel 3. Hasil Uji Reliabilitas

\begin{tabular}{cccc}
\hline Variabel & Koefisien Alpha & Pembanding & Ket \\
\hline Instore $(\mathrm{X} 1)$ & 0,770 & 0.6 & Reliabel \\
Outstore $(X 2)$ & 0,774 & 0.6 & Reliabel \\
Keputusan Pembelian $(\mathrm{Y})$ & 0,840 & 0.6 & Reliabel \\
\hline
\end{tabular}

Berdasarkan hasil uji reliabilitas dapat disimpulkan bahwa semua variabel tersebut memiliki nilai koefisien Alpha Cronbach lebih besar dari 0,6 sehingga dapat dikatakan instrumen pertanyaan yang digunakan dalam penelitian ini sudah reliabel atau dapat dihandalkan. Jadi pengukuran ini jika digunakan berulang-ulang terhadap subjek dan 
kondisi yang sama maka akan menghasilakn hasil yang relatif konsisten

Hasil analisis data, persamaan regresi digunakan mengetahui bentuk hubungan antara variabel bebas dengan variabel terikat yaitu instore atmosphere $\quad\left(\mathrm{X}_{1}\right), \quad$ outstore atmosphere $\left(\mathrm{X}_{2}\right)$ terhadap variabel terikat yaitu keputusan pembelian (Y). Dengan menggunakan bantuan SPSS for Windowsver 21.00 didapat model regresi seperti pada Tabel 4 sebagai berikut:

Tabel 4. Hasil Analisis Regresi Linear Berganda

\begin{tabular}{lccc}
\hline \multicolumn{1}{c}{ Variabel } & Standardized Coefficients & $\mathrm{T}$ & Sig. \\
\hline Instore (X1) & 0,546 & 5,378 & 0,000 \\
Outstore (X2) & 0,438 & 4,588 & 0,001 \\
\hline
\end{tabular}

Penilaian disini tidak ada nol mutlak, karena skala pengukuran data menggunakan skala likert dan juga nilai beta tidak dapat diinterpretasikan karena variabel terikat yang diteliti tidak bisa dinterpretasikan dengan angka, maka digunakan persamaan regresi menggunakan standardized coefficients:

$$
Y=\beta_{1} X_{1}+\beta_{2} X_{2}
$$

Berdasarkan pada Tabel 4. didapatkan persamaan regresi:

$$
\mathrm{Y}=0,546 \mathrm{X}_{1}+0,438 \mathrm{X}_{2}
$$

Dari persamaan di atas dapat diinterpretasikan sebagai berikut: Keputusan pembelian konsumen akan mantap untuk setiap instore atmosphere yang membuat konsumen merasa nyaman yang dilakukan oleh Rumah Makan Inggil. Jadi, apabila instore atmosphere membuat konsumen merasa nyaman, maka keputusan pembeliankonsumen akan semakin mantap, ini dikarenakan hasil kofesien regresi bernilai positif.

Keputusan pembelian konsumen akan mantap untuk setiap outstore atmosphere yang menarik yang dilakukan oleh Rumah Makan Inggil. Jadi, apabila outstore atmosphere menarik, maka keputusan pembelian konsumen akan semakin mantap, ini dikarenakan hasil kofesien regresi bernilai positif.

Tabel 5. Koefisien Korelasi dan Determinasi

\begin{tabular}{cccc}
\hline Model & $\mathrm{R}$ & $\mathrm{R}$ Square & Adjusted R Square \\
\hline 1 & 0,749 & 0,561 & 0,543 \\
\hline
\end{tabular}

Koefisien determinasi digunakan untuk menghitung besarnya pengaruh atau kontribusi variabel bebas terhadap variabel terikat. Dari analisis pada Tabel 5. diperoleh hasil koefisien determinasi (adjusted $\mathrm{R}^{2)}$ sebesar 0,543. Artinya bahwa 54,3\% variabel keputusan pembelian akan dipengaruhi oleh variabel bebasnya, yaitu instore atmosphere $\left(\mathrm{X}_{1}\right)$ dan outstore atmosphere $\left(\mathrm{X}_{2}\right)$. Sedangkan sisanya $45,7 \%$ variabel keputusan pembelian akan dipengaruhi oleh variabel-variabel yang lain yang tidak dibahas dalam penelitian ini.

Uji $\mathrm{F}$ digunakan untuk menguji pengaruh secara bersama-sama atau simultan variabel bebas $(\mathrm{X})$ terhadap variabel terikat (Y). Diduga $X_{1}$, yaitu Instore Atmosphere dan Outstore 
Atmosphere terhadap keputusan pembelian konsumen di Rumah Makan Inggil Kota Malang. Berdasarkan perhitungan regresi didapat nilai $\mathrm{F}$ hitung sebesar 15,209. Perbandingan nilai $\mathrm{F}_{\text {hitung }}$ dan $\mathrm{F}_{\text {tabel }}$ adalah $\mathrm{F}_{\text {hitung }} 15,209>\mathrm{F}_{\text {tabel }}$ 3,633. Berdasarkan hasil perbandingan yang telah dilakukan, maka dapat diambil kesimpulan bahwa hipotesa 1 diterima, Ho ditolak dan Ha diterima, yang menjelaskan Instore Atmosphere dan Outstore Atmosphere secara simultan berpengaruh signifikan terhadap keputusan pembelian konsumen di Rumah Makan Inggil Kota Malang.

Uji t ini dilakukan untuk mengetahui apakah semua variabel bebas (X) secara individu (parsial) dapat memberikan pengaruh yang nyata (signifikan) terhadap variabel terikat (Y). Diduga $X_{2}$ yaitu Instore Atmosphere dan Outstore Atmosphere mempunyai pengaruh yang signifikan dan positif terhadap keputusan pembelian konsumen di Rumah Makan Inggil Kota Malang. Berdasarkan hasil perhitungan regresi, pengambilan keputusan dilakukan dengan melihat perbandingan antara nilai $t_{\text {hitung }}$ dengan nilai $t_{\text {tabel }}$ pada $(\alpha)$ yang telah ditetapkan. Besarnya nilai $t_{\text {hitung }}$ dengan nilai $t_{\text {tabel }}$ dapat dilihat pada Tabel 6 sebagai berikut:

Tabel 6. Perbandingan Nilai $t_{\text {hitung }}$ dengan $t_{\text {tabel }}$

\begin{tabular}{ccccc}
\hline Variabel & $\mathrm{T}_{\text {hitung }}$ & $\mathrm{T}_{\text {tabel }}$ & Sig & Keterangan \\
\hline Instore Atmosphere X1 & 5,378 & 1,956 & 0,000 & Berpengaruh Signifikan \\
Outstore Atmosphere X2 & 4,588 & 1,956 & 0,001 & Berpengaruh Signifikan \\
\hline
\end{tabular}

Pengaruh variabel Instore Atmosphere $\left(\mathrm{x}_{1}\right)$ terhadap Keputusan Pembelian konsumen di Rumah Makan Inggil (Y). Dari hasil perhitungan parsial menunjukkan bahwa pada taraf nyata $5 \%$ ( $\alpha$ $=0,05$ ) dengan tingkat kepercayaan 95\% diperoleh nilai ttabel sebesar 1,956. Dengan pengujian statistik diperoleh nilai thitung sebesar 5,378, karena nilai $t_{\text {hitung }}>{ } t_{\text {abel }}(5,378>$ 1,956). Maka dapat dikatakan bahwa secara parsial variabel Instore Atmosphere $\left(\mathrm{x}_{1}\right)$ berpengaruh signifikan terhadap keputusan pembelian rumah makan Inggil.
Pengaruh variabel Outstore Atmosphere $\left(\mathrm{x}_{1}\right)$ terhadap Keputusan Pembelian konsumen di Rumah Makan Inggil (Y). Dari hasil perhitungan parsial menunjukkan bahwa pada taraf nyata 5\% ( $\alpha$ $=0,05)$ dengan tingkat kepercayaan 95\% diperoleh nilai ttabel sebesar 1,956. nilai thitung sebesar 4,588, sehingga nilai $\mathrm{t}_{\text {hitung }}>_{\mathrm{Tt}_{\mathrm{abel}}}(4,588>$ 1,956). Maka dapat dikatakan bahwa secara parsial variabel Outstore Atmosphere $\left(\mathrm{x}_{2}\right)$ berpengaruh signifikan terhadap keputusan pembelian konsumen di Rumah Makan Inggil.

Tabel 7. Hasil Uji Pengaruh Dominan

\begin{tabular}{cc}
\hline Variabel & Standardized Coeficient Beta \\
\hline Instore & 0,546 \\
Outstore & 0,438 \\
\hline
\end{tabular}


Tabel 7 menunjukkan hasil koefisien regresi (b) variabel Instore Atmosphere mempunyai pengaruh dominan terhadap keputusan pembelian rumah makan Inggil di Kota Malang. Hal tersebut dikarenakan koefisien regresi (Standardized Coeffucients Beta) pada variabel tersebut mempunyai nilai besar jika dibandingkan dengan variabel Outstore Atmosphere. Pengaruh Store Atmosphere yang terdiri dari Instore Atmosphere dan Outstore Atmosphere secara simultan terhadap keputusan pembelian. Berdasarkan hasil análisis data yang telah dilakukan maka dapat diketahui store atmosphere yang terdiri dari Instore Atmosphere dan Outstore Atmosphere berpengaruh secara simultan atau bersama-sama terhadap keputusan pembelian konsumen di Rumah Makan Inggil. Pengaruh Store Atmosphere yang terdiri dari Instore Atmosphere dan Outstore Atmosphere secara parsial terhadap keputusan pembelian

Instore atmosphere berpengaruh terhadap keputusan pembelian Berdasarkan hasil analisis data yang telah dilakukan maka dapat diketahui bahwa instore atmosphere secara parsial berpengaruh terhadap keputusan pembelian. Adanya Pengaruh tersebut menunjukkan bahwa semakin instore atmosphere membuat konsumen merasa nyaman maka keputusan pembelian konsumen akan semakin mantap di Rumah Makan Inggil. Apabila ditinjau dari instore atmosphere menunjukkan bahwa fasilitas yang dimiliki Rumah Makan Inggil yang meliputi tata letak meja kursi tertata rapi, tata letak lukisan atau pajangan yang indah, tata letak lampu yang menarik, tata letak panggung musik yang tepat atau nyaman, alunan suara atau musik sesuai konsep khas Jawa Timur tempo dulu, bau pewangi yang segar, meja kursi sesuai konsep khas Jawa Timur tempo dulu, warna dinding serasi dengan konsep di dalam ruangan, dan model desain pajangan dinding yang bagus dan artistik. Berbagai upaya senantiasa dilakukan oleh pihak Rumah Makan dimaksudkan untuk memberikan fasilitas yang nyaman untuk menciptakan keputusan pembelian konsumen.

Outstore atmosphere berpengaruh terhadap keputusan pembelian. Berdasarkan hasil analisis data yang telah dilakukan maka dapat diketahui bahwa outstore atmosphere secara parsial berpengaruh terhadap keputusan pembelian. Adanya Pengaruh tersebut menunjukkan bahwa semakin menarik instore atmosphere maka keputusan pembelian konsumen akan semakin mantap di Rumah Makan Inggil. Apabila ditinjau dari outstore atmosphere menunjukkan bahwa fasilitas yang dimiliki Rumah Makan Inggil yang meliputi letak papan nama yang terlihat jelas, letak parkir yang nyaman, pepohonan rindang yang menyejukkan, tekstur dinding yang bagus, tekstur papan nama klasik yang menarik, bentuk bangunan menawan yang terlihat elegan, model desain papan nama klasik mencerminkan keunikan. Berbagai upaya senantiasa dilakukan oleh pihak Rumah Makan Inggi yang dimaksudkan untuk memberikan kesan menarik sehingga mampu mendorong terciptanya keputusan pembelian konsumen. 
Store Atmosphere yang terdiri dari Instore Atmosphere dan Outstore Atmosphere yang berpengaruh dominan terhadap keputusan pembelian konsumen di Rumah Makan Inggil. Berdasarkan hasil analisis menunjukkan bahwa yang memiliki pengaruh dominan terhadap keputusan pembelian adalah instore atmosphere. Konsumen lebih mempertimbangkan instore atmosphere yang dimiliki Rumah Makan Inggil. Hal ini menunjukkan bahwa instore atmosphere merupakan salah satu faktor yang perlu diberikan perhatian khusus atau lebih diperhatikan oleh rumah makan inggil sehingga harus senantiasa meningkatkan dan mempertahankan suasana rumah makan inggil.

\section{SIMPULAN}

Berdasarkan hasil analisis dan pembahasan yang berkaitan dengan pengaruh store atmosphere yangterdiri dari instore atmosphere dan outstore atmosphere berpengaruh terhadap keputusan pembelian Rumah Makan Inggil di Kota Malang maka dapat ditarik kesimpulan, yaitu Store atmosphere yang terdiri dari instore atmosphere dan outstore atmosphere secara simultan dan parsial berpengaruh signifikan terhadap keputusan pembelian konsumen Rumah Makan Inggil di Kota Malang, variabel instore atmosphere mempunyai pengaruh dominan terhadap keputusan pembelian konsumen Rumah Makan Inggil di Kota Malang.

\section{DAFTAR PUSTAKA}

Ghozali, Imam, 2006, Aplikasi Analisisi Multivariat Dengan Program SPSS. Edisi 3. Yogyakarta: Andi

Levi, Michael, \& Weitz, Bortom A, 2001, Retailing Management, Fourth edition, Richard D.Irwin Inc

$\begin{array}{lrr}\text { Management. } & \text { 2009. } & \begin{array}{r}\text { Retailing } \\ \text { International }\end{array} \\ \text { Edition. Edisi } & 7 . & \text { New York: } \\ \text { McGraw-Hill. } & & \end{array}$

Kotler, Philip dan Amstrong, 2003. Dasar-Dasar Manajemen Pemasaran Jakarta: PT.Indeks.

Kotler, P., dan Keller K.L., 2008, Perilaku Konsumen, Edisi 12, Penerbit Indeks, Jakarta

Kotler, Phillip. 2008. Manajemen Pemasaran. Penerbit Indeks, Jakarta

2009. Manajemen Pemasaran. Edisi Milenium 1. Jakarta. PT. Prenhallindo. 2005, Manajemen Pemasaran. Edisi Kesebelas. Jilid 2. Jakarta: Penerbit Indeks.

Schiffman, Leon G. \& Kanuk, Lesllie Lazar. 2007. Perilaku Kosumen. Edisi Ketujuh. Jakarta: Indeks.

Sugiyono. 2005. Metode Penelitian Kualitatif. Bandung: Alfabeta. 2008. Metode Penelitian Bisnis. Bandung : CV Alfabeta. , 2011. Metode Penelitian Kuantitatif, Kualitatif, dan R\&D. Penerbit Alfabeta. Bandung.

Sujarweni, Wiratnaa. 2015. Metode Penelitian Bisnis Ekonomi. Pustaka Baru Press. Yogyakarta.

Sutisna dan Pawitra, 2001. Perilaku Konsumen dan Komunikasi Pemasaran, Bandung: Penerbit PT. Remaja Rosdakary. 